\title{
Effects of Subsidy on Food Consumption Pattern in Rural and Urban Households of Western Tamil Nadu, India
}

\author{
M. Uma Gowri* and T.R. Shanmugam \\ Department of Agricultural Economics, Centre for Agricultural and Rural Development Studies, \\ Tamil Nadu Agricultural University, Coimbatore - 641 003, Tamil Nadu, India \\ *Corresponding author
}

\section{A B S T R A C T}

The main focus of the study was to assess the impact of food subsidy on consumption of rural and urban households in Western Tamil Nadu. Almost Ideal Demand System and

\begin{tabular}{|l|}
\hline Key w or d s \\
Consumption \\
pattern, Subsidy \\
effect, Income, \\
Consumption \\
function, \\
Households \\
Article Info \\
\hline $\begin{array}{l}\text { Accepted: } \\
\text { 15 March } 2017 \\
\text { Available Online: } \\
\text { 10 April } 2017\end{array}$ \\
\hline
\end{tabular}
Household Food Consumption Function were used to study the consumption pattern of different income groups and analyse the effect of food subsidy on consumption pattern. The results of expenditure pattern had revealed that as income increased the percentage of expenditure of food commodities decreased. Increase in real income the HIG increased their expenditure on milk and milk products and animal products in both the sectors. Among the income groups, the LIG increased their expenditure share on more items with any increase in real income in both the sectors. The total expenditure on food subsidy decreased with increased income. The expenditure on subsidized other cereals was more in the higher income groups indicating thereby that purchase of wheat was more by this group from the Fair Price Shops. The ratio of subsidy food to total food was decreasing from 55.60 per cent in rural LIG to 3.84 per cent in rural HIG and it was 51.34 per cent and 3.68 per cent, respectively for their urban counterparts. In LIG, their total rice consumption was met through Free Rice Scheme of the Government of Tamil Nadu, over eight per cent of the total oil consumption purchased from the subsidy shops. But price of oil, and sugar to a large extent affected the LIG. The subsidy wheat price increased would affect the HIG in both the sectors.

\section{Introduction}

India is a rapidly growing developing country, but has a larger food-insecure population than all of Sub-Saharan Africa (Krishnamurthy et al., 2014). Given the prevalence of chronic malnutrition, India is engaged in a prolonged debate about increasing expenditures on its national food aid program, the Public Distribution System (PDS). India spent nearly one percent of its gross domestic product on the PDS in 2012 (FAO, 2012), and that amount likely will increase under the National Food Security Act (NFSA) of 2013, which became law in September 2013 (Meade et al., 2013). The Public Distribution System (PDS) is one of the biggest anti-poverty programmes of the Indian government (Khera and Reetika, 2011). The PDS provides assistance to below poverty line (BPL) households in the form of a monthly quota of subsidised goods including rice, wheat, sugar, edible oil and kerosene, though a network of 4.9 lakh fair price shops across the country (Puri and Ragahv, 2012). The primary aim of the programme is to improve the nutritional status 
of food insecure households by providing them supplementary food grains. Despite serious operational issues ranging from faulty targeting to high levels of leakage and corruption, the PDS remains a critical form of assistance to poor households in India. Hence, the present study was taken to study the effect of food subsidy on food consumption of rural and urban households in the Western Tamil Nadu region. The main objectives include to study the consumption and expenditure pattern of different income groups in both urban and rural households. And to analyse the impact of subsidy particularly PDS and NMS on food and nutritional consumption of different income groups in both urban and rural households. Also to suggest appropriate policy options.

\section{Materials and Methods}

The western region of Tamil Nadu comprising coimbatore, erode and tirupur districts was chosen for the study. Multistage random sampling technique was followed. In first stage, one block was selected at random from each of the districts. For the urban category, sample households residing in the city limit and around five $\mathrm{km}$ radius from city was selected. To compare the consumption of rural and urban households in the study area, three villages from each of the blocks were selected, again at random.

The final stage of sampling unit consisted of selection of households. Totally, 180 rural and 180 urban households were selected. Based on the report -"Chapter on Housing Requirement Projection for IX plan (20072012), the selected households were post stratified into three groups viz., Low Income Group (LIG) earning less than Rs7300/ month, Middle Income Group (MIG) earning Rs.7301-14500/month and High Income Group HIG earning more than Rs.14500/month.

\section{Tools of analysis}

\section{Empirical frame work of AIDS model}

The following form of AIDS model was used in the present analysis to estimate the system of demand functions for food items like cereals, pulses, oils, fruits and vegetables, sugar, meat products, milk, spices and condiments. From the estimated demand functions price and income elasticities were derived. Following Deaton and Muellbauer (1980) the linear approximate AIDS model was used.

$\mathrm{W}_{\mathrm{i}}=\mathrm{a}_{\mathrm{i}}+\Sigma \mathrm{b}_{\mathrm{ij}} \ln \mathrm{P}_{\mathrm{j}}+\mathrm{c}_{\mathrm{i}} \ln \left(\mathrm{X} / \mathrm{P}^{*}\right)$

Where, $\mathrm{W}_{\mathrm{i}}$ - Average budget share of the $\mathrm{i}$ th commodity, $P_{j}$ - Price of the $j$ th commodity, $X$ - Expenditure per capita on food commodities (rice, other cereals, pulses, oil and fat, vegetables, fruits, meat, milk, sugar, processed food and health drinks, others), Ln $\mathrm{P}^{*}$ - Price Index, $\mathrm{b}_{\mathrm{ij},}, \mathrm{c}_{\mathrm{i}}$ - Parameters, $\mathrm{i} \ldots \mathrm{j}$ $1,2 \ldots \ldots . .11$.

For the Aids to be consistent with the properties of consumer demand theory the structural parameters of AIDS model were estimated subjected to Engel aggregation, homogeneity and symmetry restrictions.

\section{Household food consumption function}

To estimate the impact of food subsidy on household food consumption, the linear model used by Garcia et al., (1993) was modified and used in the present study.

$C=b_{0}+b_{1} Y+b_{2} S+b_{3} M+b_{4} E+b_{5} P_{1}+b_{6} P_{2}+$ $\mathrm{b}_{7} \mathrm{P}_{3}+\mathrm{b}_{8} \mathrm{P}_{4}$

$\mathrm{C}=$ Per capita consumption expenditure on food items (Rs.)

$\mathrm{S}=$ Subsidy (Rs.)

$\mathrm{Y}=$ Per capita real income (Rs.)

$\mathrm{M}=$ Family size of the household (Number) 
$E=$ Number of years (Number)

$\mathrm{P}_{1}=$ Price paid for rice (Rs.)

$\mathrm{P}_{2}=$ Price paid for other cereals (Rs.)

$\mathrm{P}_{3}=$ Price paid for oil (Rs.)

$\mathrm{P}_{\mathbf{4}}=$ Price paid for sugar (Rs.)

$\mathrm{b}_{0 \ldots \ldots . . . .} \mathrm{b}_{8}$ are the parameters to be estimated (Rs.)

The income variable was specified in the model to estimate MPC (dc/dy). The market price paid by the households for rice, cooking oil, other cereals and sugar were also used as independent variables in the regression to derive the direct price effect on food consumption, since in the study region the food items viz., rice, wheat, oil and sugar were frequently distributed during the study period. The subsidy includes the value of subsidy realized through essential items distributed through PDS and the value of food consumed under NMS. The shifter variables household size and education were also included in the function as explanatory variables. A positive and significant subsidy coefficient would indicate that income transfers embodied in the subsidy have a higher marginal propensity to consume than other household income and vice versa. If the coefficient of subsidy is not significantly different from zero, the marginal propensity to consume to acquire food does not change with the changing.

\section{Results and Discussion}

The estimated coefficient from the AIDS model showed that the people in the rural sector enhance their expenditure share on rice, oil, pulses, milk and milk products, while in the urban sector they increased their expenditure share in pulses, other cereals, fruits, milk and milk products, meat and meat products and processed food and health drinks with an increase in real income. This showed the Engel phenomenon. Thus both the urban and rural people were consistent in increasing the expenditure share on pulses, milk and milk products with an increase in real income. It led to the conclusion that people intended to spent more on protein rich foods. The LIG in rural people spread their expenditure on more commodities with a change in real income than the other groups. The same trend appeared in the LIG in urban people also. But in case of MIG and HIG in the both sectors, people spent their expenditure more on nutritional commodity. So, these people attained food and nutritional security than LIG. Thus the rural LIG people were more sensitive to even little changed in real income (Tables 1-6).

\section{Subsidy effects on household food expenditure}

Average value of consumption expenditure in food subsidy schemes, such as Public Distribution System (PDS) and Noon Meal Scheme (NMS) were analyzed and presented income group wise in table 7. It could be seen that the value of food subsidy was Rs.76.38 per month for rural LIG and declined as income level increased. For example it was Rs.69.36 in rural HIG and Rs. 69.01 in urban HIG through PDS. The food subsidy realized from NMS by rural LIG was Rs. 257.96. Similar trend was also observed for urban households. The total food subsidy varied from Rs. 69.36 to Rs. 334.34 across households in rural region. The urban LIG enjoyed a subsidy of Rs. 314.30 per month as against Rs. 69.01 by urban HIG. Among the subsidy items, expenditure on rice and oil was more among LIG, whereas the expenditure on sugar and other cereals (Wheat) was more in HIG households. The rice was availed at free of cost through Public Distribution System, and it encouraged food and nutritional security among the LIG in both the sectors. The value of food purchased through NMS was high in the poor income group (Rs. 257.96 in rural and Rs. 239.04 in urban), indeed a desirable feature. It declined, when move from LIG to HIG. The consumption through NMS was nil 
for the HIG households in both the sectors. The budget share on total food subsidy, PDS and NMS to the total food expenditure are presented in table 8 . The percentage of total food subsidy to total food expenditure decreased from 55.60 in rural LIG to 3.84 in rural HIG and the respective figures for urban LIG and HIG ranged from 51.34 to 3.68. The rural LIG people met 43.33 per cent of their average consumption from NMS and the urban LIG 38.45 per cent. The LIG availed the subsidy rice of PDS to meet the rice consumption needs. It revealed that any change in the price policy on subsidy rice would adversely affect the weaker sections of the people more than anyone else. But the price rise in the wheat would adversely influence the HIG.

In general, both PDS and NMS helped the LIG to enhance their food consumption level. Hence these subsidy schemes must be further strengthened to improve the nutritional level, to reduce the malnutrition and alleviate poverty among vulnerable and weaker sections of the people both in rural and urban areas. The estimated parameters of household food consumption function are presented in table 9.

The coefficient of household income was positive and significant for all the income groups in both rural and urban sectors i.e. one unit increase in income would increase the per capita household food expenditure by 0.92 , $0.77,0.62$ respectively for $\mathrm{LIG}, \mathrm{MIG}, \mathrm{HIG}$ in rural and it was $0.94,0.84,0.63$ respectively for LIG, MIG, HIG in urban. It indicated that the influence of household income on food consumption was higher in LIG than MIG and HIG in both the sectors. Normally LIG were underfed and hence increase in income might influence him to go for food consumption immediately.

This result confirmed Engel's law of consumption. Between rural and urban sector, the impact of income on consumption was higher in urban than rural. Food and mess facilities available in the urban are might influence the urban consumers to go for food consumption. Food subsidies might cause a change in time allocation in general and in the allocation of time to income earning activities in particular for all income groups in the society. Thus, it might be hypothesized that the subsidies reduced the time allocated to income earning activities. This implied substitution between the real income embodied in the subsidies and household real income from other sources.

The household size coefficient was negative and significant for all the income groups in both rural and urban sectors. It showed that the presence of more family members reduced the per capita food consumption expenditure.

The absolute values of coefficients showed that the reduction of per capita food consumption increased with a decrease in income. This showed the Engel's phenomenon. Household size was generally more closely related to food expenditure. The education coefficients for rural HIG and MIG and HIG income groups of urban were positive and significant. It confirmed the Engel's law. Moreover higher education led to better understanding of the importance of adequate nutrition.

The coefficient of food subsidy was positive for all the income groups in the society. But it was significant for LIG and MIG income groups of both rural and urban centres. It indicated that for this section of people the share of food subsidy significantly increased their total food consumption.

Moreover positive and significant subsidy coefficient for LIG and MIG in both the sectors indicated that the income transfers embodied in the subsidy programme had a higher marginal propensity to consume than other household income. 
Table.1 Parameters estimates based on almost ideal demand system for major food commodities in rural LIG

\begin{tabular}{|c|c|c|c|c|c|c|c|c|c|c|}
\hline Variables & $\begin{array}{l}\text { Other } \\
\text { cereals }\end{array}$ & Pulses & Oil & Vegetables & Fruits & $\begin{array}{c}\text { Meat and meat } \\
\text { products }\end{array}$ & $\begin{array}{l}\text { Milk and } \\
\text { milk } \\
\text { products }\end{array}$ & Sugar & $\begin{array}{c}\text { Processed food } \\
\text { and Health } \\
\text { rinks } \\
\end{array}$ & Others \\
\hline Other cereals & 0.0056 & 0.0325 & $0.0033 *$ & -0.0661 & -0.0211 & -0.0219 & -0.0116 & 0.0509 & -0.0283 & -0.0122 \\
\hline Pulses & 0.0325 & 0.0241 & 0.0176 & -0.0405 & -0.0399 & -0.003 & $-0.0057^{*}$ & 0.0121 & -0.0441 & 0.0154 \\
\hline Oil & $-0.0033^{*}$ & 0.0176 & 0.0104 & $-0.048 *$ & -0.0004 & $0.0003 *$ & 0.0177 & -0.0055 & -0.0425 & -0.0184 \\
\hline Vegetables & -0.0661 & -0.0405 & $-0.048 *$ & -0.0588 & 0.0055 & -0.0134 & -0.043 & -0.0425 & 0.0184 & 0.012 \\
\hline Fruits & -0.0211 & -0.0399 & -0.0004 & 0.0055 & -0.0054 & -0.0217 & -0.0369 & -0.0187 & 0.0076 & -0.0192 \\
\hline $\begin{array}{l}\text { Meat and } \\
\text { meat products }\end{array}$ & -0.0219 & -0.003 & $-0.0003^{*}$ & -0.0134 & -0.0217 & -0.0046 & -0.0041 & -0.0218 & 0.0115 & 0.0022 \\
\hline $\begin{array}{l}\text { Milk and milk } \\
\text { products }\end{array}$ & -0.0116 & $-0.0057 *$ & 0.0177 & 0.043 & -0.0369 & -0.0041 & -0.0379 & 0.0052 & 0.0051 & 0.0041 \\
\hline Sugar & 0.0509 & 0.0121 & 0.0055 & -0.0425 & -0.0187 & -0.0218 & 0.0052 & -0.0136 & 0.0421 & 0.0469 \\
\hline $\begin{array}{l}\text { Processed } \\
\text { food and } \\
\text { Health drinks }\end{array}$ & -0.0283 & -0.0441 & -0.0425 & 0.0184 & 0.0076 & -0.0115 & 0.0051 & 0.0421 & $-0.028 *$ & -0.0263 \\
\hline Others & -0.0122 & 0.0154 & -0.0184 & -0.012 & -0.0192 & -0.0022 & -0.0041 & -0.0469 & 0.0263 & 0.0044 \\
\hline Intercept & 0.0056 & 0.0325 & -0.0033 & -0.0661 & 0.0211 & 0.0219 & 0.0116 & -0.0509 & -0.0283 & -0.0122 \\
\hline $\begin{array}{l}\text { Total } \\
\text { Expenditure }\end{array}$ & 0.0325 & 0.0241 & 0.0176 & 0.0405 & 0.0399 & 0.003 & 0.0057 & -0.0121 & 0.0441 & 0.0154 \\
\hline
\end{tabular}

* - significant at 5 per cent. 
Table.2 Parameters estimates based on almost ideal demand system for major food commodities in rural MIG

\begin{tabular}{|c|c|c|c|c|c|c|c|c|c|c|c|}
\hline Variables & Rice & $\begin{array}{l}\text { Other } \\
\text { cereals }\end{array}$ & Pulses & Oil & Vegetables & Fruits & $\begin{array}{c}\text { Meat and } \\
\text { meat } \\
\text { products }\end{array}$ & $\begin{array}{l}\text { Milk and } \\
\text { milk } \\
\text { products }\end{array}$ & Sugar & $\begin{array}{c}\text { Processed } \\
\text { food and } \\
\text { Health } \\
\text { drinks }\end{array}$ & Others \\
\hline Rice & 0.0893 & -0.0375 & $-0.0028 *$ & -0.0576 & 0.0335 & 0.0448 & 0.0354 & 0.0501 & $-0.0402 *$ & 0.0031 & -0.0153 \\
\hline $\begin{array}{l}\text { Other } \\
\text { cereals }\end{array}$ & -0.0375 & 0.0135 & 0.0438 & -0.0006 & -0.0617 & -0.0881 & $0.0776 *$ & 0.0134 & -0.0187 & 0.0342 & 0.0423 \\
\hline Pulses & $-0.0028 *$ & 0.0438 & -0.0931 & -0.0016 & 0.0158 & 0.0058 & 0.0225 & -0.0048 & -0.0086 & 0.0027 & 0.0068 \\
\hline Oil & 0.0576 & 0.0006 & 0.0016 & -0.122 & 0.0601 & 0.0653 & $-0.1612^{*}$ & 0.0805 & 0.1221 & $-0.064 *$ & -0.063 \\
\hline Vegetables & 0.0335 & -0.0617 & 0.0158 & 0.0601 & 0.0144 & 0.0271 & $-0.0408 *$ & 0.0154 & 0.0194 & $-0.0093 *$ & -0.74 \\
\hline Fruits & 0.0448 & -0.0881 & 0.0058 & 0.0653 & 0.0271 & 0.0161 & $0.012^{*}$ & -0.0099 & -0.0139 & $-0.0113 *$ & -0.0114 \\
\hline $\begin{array}{l}\text { Meat and } \\
\text { meat } \\
\text { products }\end{array}$ & 0.0354 & $0.0776^{*}$ & 0.0225 & $-0.1612 *$ & $-0.0408 *$ & $-0.012 *$ & 0.0227 & $0.0097 *$ & 0.0172 & 0.0613 & -0.0224 \\
\hline $\begin{array}{l}\text { Milk and } \\
\text { milk } \\
\text { products }\end{array}$ & 0.0501 & 0.0134 & -0.0048 & 0.0805 & 0.0154 & -0.0099 & $0.0097 *$ & 0.0302 & 0.0028 & 0.0718 & 0.0639 \\
\hline Sugar & $-0.0402 *$ & -0.0187 & -0.0086 & 0.1221 & 0.0194 & -0.0139 & 0.0172 & 0.0028 & 0.0263 & -0.0081 & 0.1017 \\
\hline $\begin{array}{l}\text { Processed } \\
\text { food and } \\
\text { Health } \\
\text { drinks }\end{array}$ & 0.0031 & 0.0342 & 0.0027 & $-0.064 *$ & $-0.0093 *$ & $-0.0139 *$ & 0.0613 & 0.0718 & -0.0081 & 0.021 & -0.0066 \\
\hline Others & -0.0153 & 0.0423 & 0.0068 & -0.063 & -0.74 & -0.0114 & -0.0224 & 0.0639 & 0.1017 & -0.0066 & -0.0135 \\
\hline Intercept & 0.7743 & -0.0288 & -0.0836 & -0.1555 & -0.2711 & 0.4793 & -0.3781 & 0.4293 & 0.2207 & 0.007 & 0.0065 \\
\hline $\begin{array}{l}\text { Total } \\
\text { Expenditure }\end{array}$ & 0.0131 & -0.0297 & 0.0144 & 0.0593 & 0.0043 & 0.0049 & -0.0006 & 0.0111 & 0.0095 & 0.0033 & 0.0087 \\
\hline
\end{tabular}

\footnotetext{
* - significant at 5 per cent
} 
Table.3 Parameters estimates based on almost ideal demand system for major food commodities in rural HIG

\begin{tabular}{|c|c|c|c|c|c|c|c|c|c|c|c|}
\hline Variables & Rice & $\begin{array}{c}\text { Other } \\
\text { cereals }\end{array}$ & Pulses & Oil & Vegetables & Fruits & $\begin{array}{c}\text { Meat and } \\
\text { meat } \\
\text { products }\end{array}$ & $\begin{array}{l}\text { Milk and } \\
\text { milk } \\
\text { products }\end{array}$ & Sugar & $\begin{array}{c}\text { Processed } \\
\text { food and } \\
\text { Health } \\
\text { drinks }\end{array}$ & Others \\
\hline Rice & 0.1405 & 0.0056 & 0.0325 & -0.0033 & 0.066 & 0.0213 & 0.0219 & 0.0116 & -0.0509 & -0.0283 & 0.0257 \\
\hline $\begin{array}{l}\text { Other } \\
\text { cereals }\end{array}$ & 0.0056 & 0.0225 & 0.0241 & $0.0176^{*}$ & 0.0405 & -0.0399 & 0.003 & 0.0057 & $0.0121 *$ & 0.0441 & 0.0154 \\
\hline Pulses & 0.0325 & 0.0241 & 0.0372 & $0.0104 *$ & 0.0486 & -0.0004 & 0.0003 & 0.0177 & 0.0055 & -0.0425 & -0.0184 \\
\hline Oil & -0.0033 & $0.0176^{*}$ & $0.0104 *$ & 0.0156 & 0.0588 & 0.0055 & -0.0134 & 0.0432 & $0.0654 *$ & 0.0071 & -0.0364 \\
\hline Vegetables & 0.066 & 0.0405 & 0.0486 & 0.0588 & -0.0962 & 0.0415 & 0.0054 & $-0.0217^{*}$ & 0.0369 & -0.0187 & 0.0076 \\
\hline Fruits & 0.0213 & -0.0399 & -0.0004 & 0.0055 & 0.0415 & 0.0271 & -0.0221 & $-0.0046^{*}$ & 0.0041 & -0.0218 & 0.0115 \\
\hline $\begin{array}{l}\text { Meat and } \\
\text { meat } \\
\text { products }\end{array}$ & 0.0219 & 0.003 & 0.0003 & -0.0134 & 0.0054 & -0.0221 & 0.0042 & 0.0379 & 0.0052 & -0.0051 & -0.0041 \\
\hline $\begin{array}{l}\text { Milk and } \\
\text { milk } \\
\text { products }\end{array}$ & 0.0116 & 0.0057 & 0.0177 & 0.0432 & $-0.0217^{*}$ & $-0.0046^{*}$ & 0.0379 & 0.1718 & 0.0136 & $-0.0421 *$ & -0.0469 \\
\hline Sugar & -0.0509 & $0.0121^{*}$ & 0.0055 & $0.0654 *$ & 0.0369 & 0.0041 & 0.0052 & 0.0136 & 0.0002 & 0.0134 & -0.028 \\
\hline $\begin{array}{l}\text { Processed } \\
\text { food and } \\
\text { Health } \\
\text { drinks }\end{array}$ & -0.0283 & 0.0441 & -0.0425 & 0.0071 & -0.0187 & -0.0218 & -0.0051 & $-0.0421 *$ & 0.0134 & 0.0121 & -0.0203 \\
\hline Others & 0.0257 & 0.0154 & -0.0184 & -0.0364 & 0.0076 & 0.0115 & -0.0041 & -0.0469 & -0.028 & -0.0203 & 0.0068 \\
\hline Intercept & 0.6909 & -0.1628 & -0.0854 & -0.0364 & 0.2489 & -0.0154 & -0.0381 & -0.0473 & 0.4504 & -0.0082 & 0.0034 \\
\hline $\begin{array}{l}\text { Total } \\
\text { Expenditure }\end{array}$ & 0.0552 & 0.0029 & 0.0021 & 0.1186 & $0.0272 *$ & $0.0011^{*}$ & 0.0126 & $0.0002 *$ & 0.0101 & $0.0411 *$ & -0.0054 \\
\hline
\end{tabular}

\footnotetext{
* - significant at 5 per cent
} 
Table.4 Parameters estimates based on almost ideal demand system for major food commodities in urban LIG

\begin{tabular}{|c|c|c|c|c|c|c|c|c|c|c|}
\hline Variables & $\begin{array}{l}\text { Other } \\
\text { cereals }\end{array}$ & Pulses & Oil & Vegetables & Fruits & $\begin{array}{c}\text { Meat and } \\
\text { meat } \\
\text { products }\end{array}$ & $\begin{array}{l}\text { Milk and } \\
\text { milk } \\
\text { products }\end{array}$ & Sugar & $\begin{array}{c}\text { Processed } \\
\text { food and } \\
\text { Health } \\
\text { drinks }\end{array}$ & Others \\
\hline $\begin{array}{l}\text { Other } \\
\text { cereals }\end{array}$ & 0.0064 & $-0.0084 *$ & 0.0343 & $-0.0071 *$ & $-0.0417^{*}$ & 0.0029 & -0.0004 & -0.0069 & 0.0753 & 0.0231 \\
\hline Pulses & $-0.0084 *$ & 0.0069 & -0.0202 & $-0.4272 *$ & 0.1429 & -0.0399 & 0.0634 & 0.0689 & -0.085 & -0.0087 \\
\hline Oil & 0.0343 & -0.0202 & 0.0509 & 0.0267 & 0.0742 & -0.025 & -0.0048 & -0.0227 & -0.0131 & 0.0166 \\
\hline Vegetables & $-0.0071^{*}$ & $-0.4272 *$ & 0.0267 & 0.0267 & $-0.0079 *$ & $-0.0123^{*}$ & 0.0144 & 0.0232 & -0.0559 & 0.0084 \\
\hline Fruits & $-0.0417 *$ & 0.1429 & 0.0742 & $-0.0079^{*}$ & -0.0079 & 0.0041 & 0.0126 & 0.0035 & -0.0284 & 0.0477 \\
\hline $\begin{array}{l}\text { Meat and } \\
\text { meat } \\
\text { products }\end{array}$ & 0.0029 & -0.0399 & -0.025 & $-0.0123 *$ & 0.0041 & -0.0064 & -0.0008 & -0.0375 & 0.0675 & -0.0611 \\
\hline $\begin{array}{l}\text { Milk and } \\
\text { milk } \\
\text { products }\end{array}$ & -0.0004 & 0.0634 & -0.0048 & 0.0144 & 0.0126 & -0.0008 & -0.0532 & $-0.1008^{*}$ & 0.02345 & 0.0227 \\
\hline Sugar & -0.0069 & 0.0689 & -0.0227 & 0.0232 & 0.0035 & $-0.0375^{*}$ & $-0.1008^{*}$ & 0.0189 & 0.0107 & 0.0002 \\
\hline $\begin{array}{l}\text { Processed } \\
\text { food and } \\
\text { Health } \\
\text { drinks }\end{array}$ & 0.0753 & -0.085 & $-0.0131 *$ & -0.0559 & -0.0284 & $0.0675^{*}$ & 0.02345 & 0.0107 & 0.0152 & 0.0281 \\
\hline Others & 0.0231 & -0.0087 & 0.0166 & 0.0084 & 0.0477 & -0.0611 & 0.0227 & 0.0002 & 0.0281 & -0.0243 \\
\hline Intercept & -0.0087 & 0.0166 & 0.0084 & 0.0477 & -0.0611 & 0.0227 & 0.0002 & 0.0281 & -0.0243 & -0.0023 \\
\hline $\begin{array}{l}\text { Total } \\
\text { Expenditure }\end{array}$ & 0.0929 & $0.0166^{*}$ & $0.0084^{*}$ & $0.0477 *$ & $0.0116^{*}$ & 0.0027 & 0.0002 & $0.0281 *$ & 0.0001 & -0.0027 \\
\hline
\end{tabular}

* - significant at 5 per cent 
Table.5 Parameters estimates based on almost ideal demand system for major food commodities in urban MIG

\begin{tabular}{|c|c|c|c|c|c|c|c|c|c|c|c|}
\hline Variables & Rice & $\begin{array}{l}\text { Other } \\
\text { cereals }\end{array}$ & Pulses & Oil & Vegetables & Fruits & $\begin{array}{l}\text { Meat \& } \\
\text { meat } \\
\text { products }\end{array}$ & $\begin{array}{l}\text { Milk } \\
\text { \&milk } \\
\text { products }\end{array}$ & Sugar & \begin{tabular}{l}
\multicolumn{2}{l}{ Processed } \\
food \& \\
Health \\
drinks
\end{tabular} & Others \\
\hline Rice & 0.112 & 0.0025 & -0.0002 & 0.0171 & 0.0082 & -0.0223 & 0.0152 & 0.0068 & -0.0095 & -0.0086 & 0.0279 \\
\hline $\begin{array}{l}\text { Other } \\
\text { cereals }\end{array}$ & 0.0025 & $0.0046^{*}$ & $\begin{array}{r}- \\
0.0087 *\end{array}$ & 0.0012 & 0.4231 & $0.0133^{*}$ & 0.0043 & -0.0071 & -0.0628 & -0.0043 & 0.0048 \\
\hline Pulses & $0.0002^{-}$ & -0.0087 & $0.0211^{*}$ & 0.0336 & 0.0134 & $0.0023 *$ & $0.0034^{*}$ & $0.0008 *$ & 0.0034 & 0.0614 & 0.0088 \\
\hline Oil & 0.0171 & 0.0012 & 0.0336 & 0.0041 & 0.0178 & 0.0182 & 0.008 & -0.0383 & -0.0421 & -0.0325 & 0.0351 \\
\hline Vegetables & 0.0082 & 0.4231 & 0.0134 & 0.0178 & -0.0379 & $-0.006 *$ & $-0.0176^{*}$ & 0.0004 & 0.0273 & -0.0405 & 0.0277 \\
\hline Fruits & 0.0223 & $0.0133^{*}$ & $0.0023^{*}$ & $0.0182 *$ & -0.006 & 0.0232 & 0.1151 & -0.0267 & 0.0018 & -0.0022 & 0.0269 \\
\hline $\begin{array}{ll}\text { Meat } \quad \& \\
\text { meat } \\
\text { products }\end{array}$ & 0.0152 & 0.0043 & 0.0034 & 0.008 & $-0.0176^{*}$ & 0.1151 & -0.0226 & 0.0431 & 0.026 & -0.0049 & -0.0002 \\
\hline $\begin{array}{l}\text { Milk \& milk } \\
\text { products }\end{array}$ & 0.0068 & $-0.0071 *$ & 0.0008 & $-0.0383 *$ & 0.0004 & $-0.0267 *$ & 0.0431 & 0.0235 & 0.0083 & 0.0104 & -0.0091 \\
\hline Sugar & 0.0095 & -0.0628 & 0.0034 & -0.0421 & 0.0273 & 0.0018 & 0.026 & 0.0083 & -0.0146 & -0.0857 & -0.0816 \\
\hline $\begin{array}{l}\text { Processed } \\
\text { food } \\
\text { \&Health } \\
\text { drinks }\end{array}$ & 0.0086 & -0.0043 & 0.0614 & -0.0325 & -0.0405 & -0.0022 & -0.0049 & 0.0104 & -0.0857 & -0.0115 & -0.0178 \\
\hline Others & 0.0279 & 0.0048 & 0.0088 & 0.0351 & 0.0277 & 0.0269 & -0.0002 & -0.0091 & -0.0816 & -0.0178 & 0.0042 \\
\hline Intercept & 0.4803 & 0.0198 & 0.4811 & 0.2963 & 0.0422 & -0.2038 & 0.005 & 0.0905 & 0.111 & -0.3083 & -0.0141 \\
\hline $\begin{array}{l}\text { Total } \\
\text { Expenditure }\end{array}$ & $\begin{array}{r}- \\
0.0586\end{array}$ & -0.0012 & -0.0185 & $0.001 *$ & -0.0565 & -0.0002 & -0.0048 & $0.0004 *$ & -0.016 & $0.0027 *$ & -0.0258 \\
\hline
\end{tabular}

* - significant at 5 per cent 
Table.6 Parameters estimates based on almost ideal demand system for major food commodities in urban HIG

\begin{tabular}{|c|c|c|c|c|c|c|c|c|c|c|c|}
\hline Variables & Rice & $\begin{array}{l}\text { Other } \\
\text { cereals }\end{array}$ & Pulses & Oil & Vegetables & Fruits & $\begin{array}{l}\text { Meat and } \\
\text { meat } \\
\text { products }\end{array}$ & $\begin{array}{l}\text { Milk and } \\
\text { milk } \\
\text { Products }\end{array}$ & Sugar & $\begin{array}{l}\text { Processed } \\
\text { food and } \\
\text { Health } \\
\text { drinks }\end{array}$ & Others \\
\hline Rice & 0.077 & - & $-0.0041 *$ & 0.0148 & $0.0061 *$ & $0.0756^{*}$ & 0.0018 & 0.0261 & 0.0231 & 0.0024 & 0.077 \\
\hline Other cereals & - & 0.0444 & 0.0154 & 0.0033 & 0.0008 & 0.0272 & -0.0099 & -0.0041 & -0.0609 & 0.0095 & -0.0177 \\
\hline Pulses & - & -0.0154 & $0.099 *$ & $0.0068 *$ & $-0.0121 *$ & 0.0224 & $-0.0234 *$ & -0.0212 & 0.0326 & -0.0397 & -0.0041 \\
\hline Oil & 0.0148 & 0.0033 & 0.0068 & 0.048 & 0.0142 & $-0.0211^{*}$ & $-0.0265^{*}$ & $-0.0417 *$ & 0.0088 & 0.0223 & -0.0148 \\
\hline Vegetables & 0.0061 & 0.0008 & -0.0121 & 0.0142 & 0.0117 & -0.113 & -0.0476 & $0.0561 *$ & -0.0011 & $0.0022 *$ & -0.0061 \\
\hline Fruits & 0.0756 & 0.0272 & 0.0224 & -0.0211 & -0.113 & 0.4893 & 0.0425 & -0.1542 & -0.0102 & -0.1565 & -0.0756 \\
\hline $\begin{array}{l}\text { Meat and } \\
\text { meat } \\
\text { products }\end{array}$ & 0.0018 & -0.0099 & 0.0234 & 0.0265 & $0.0476^{*}$ & $0.0425 *$ & 0.0018 & -0.0559 & 0.0137 & -0.0121 & 0.0018 \\
\hline $\begin{array}{l}\text { Milk and } \\
\text { milk } \\
\text { products }\end{array}$ & 0.0261 & 0.0041 & $-0.021 *$ & $-0.0417 *$ & 0.0561 & -0.1542 & 0.0559 & 0.1351 & $-0.3911 *$ & 0.0121 & 0.0261 \\
\hline Sugar & 0.0231 & - & 0.0326 & 0.0088 & $-0.0011 *$ & $-0.0102 *$ & 0.0137 & 0.3911 & 0.0012 & -0.1759 & 0.0231 \\
\hline $\begin{array}{l}\text { Processed } \\
\text { food and } \\
\text { Health drinks }\end{array}$ & 0.0024 & 0.0095 & 0.0397 & 0.0223 & 0.0022 & 0.1565 & $-0.0121 *$ & $-0.0121 *$ & -0.1759 & $-0.0005 *$ & -0.0024 \\
\hline Others & 0.0563 & -0.0251 & -0.029 & -0.2314 & -0.0432 & -0.0675 & -0.0043 & -0.2341 & -0.0432 & 0.0042 & 0.0563 \\
\hline Intercept & 0.7175 & 0.4397 & 0.2312 & 0.1263 & 0.6341 & 1.0166 & -1.8643 & -0.4921 & -0.6163 & 0.0744 & 0.7175 \\
\hline Total & - & -0.0434 & $0.0209 *$ & -0.0056 & -0.0599 & -0.098 & 0.0023 & $0.074 *$ & -0.0081 & $0.0035^{*}$ & -0.0694 \\
\hline
\end{tabular}


Table.7 Average value of consumption expenditure per household through public distribution system and noon meal scheme (in Rupees)

\begin{tabular}{|c|c|c|c|c|c|c|}
\hline \multirow{2}{*}{ Commodity } & \multicolumn{3}{|c|}{ Rural } & \multicolumn{3}{|c|}{ Urban } \\
\hline & LIG & MIG & HIG & LIG & MIG & HIG \\
\hline A. Total food subsidy through PDS & $\begin{array}{c}76.38 \\
(22.85)\end{array}$ & $\begin{array}{c}71.42 \\
(45.18)\end{array}$ & $\begin{array}{c}69.36 \\
(100.00)\end{array}$ & $\begin{array}{c}75.26 \\
(23.95)\end{array}$ & $\begin{array}{c}72.70 \\
(43.97)\end{array}$ & $\begin{array}{c}69.01 \\
(100.00)\end{array}$ \\
\hline Rice & 0 & 0 & 0 & 0 & 0 & 0 \\
\hline Other cereals (Wheat) & $\begin{array}{l}20.37 \\
(6.09)\end{array}$ & $\begin{array}{c}21.54 \\
(13.63)\end{array}$ & $\begin{array}{c}24.50 \\
(35.32)\end{array}$ & $\begin{array}{l}19.47 \\
(6.19)\end{array}$ & $\begin{array}{c}22.91 \\
(13.86)\end{array}$ & $\begin{array}{c}23.52 \\
(34.08)\end{array}$ \\
\hline Oil & $\begin{array}{l}27.67 \\
(8.28)\end{array}$ & $\begin{array}{c}16.45 \\
(10.41)\end{array}$ & $\begin{array}{c}10.32 \\
(14.88)\end{array}$ & $\begin{array}{l}28.45 \\
(9.05)\end{array}$ & $\begin{array}{c}17.45 \\
(10.55)\end{array}$ & $\begin{array}{c}10.26 \\
(14.87)\end{array}$ \\
\hline Sugar & $\begin{array}{l}28.34 \\
(8.48)\end{array}$ & $\begin{array}{c}33.43 \\
(21.15)\end{array}$ & $\begin{array}{c}34.54 \\
(49.80)\end{array}$ & $\begin{array}{l}27.34 \\
(8.70)\end{array}$ & $\begin{array}{c}32.34 \\
(19.56)\end{array}$ & $\begin{array}{c}35.23 \\
(51.05)\end{array}$ \\
\hline B. Food subsidy through NMS & $\begin{array}{l}257.96 \\
(77.15)\end{array}$ & $\begin{array}{c}86.65 \\
(54.82) \\
\end{array}$ & 0 & $\begin{array}{l}239.04 \\
(76.05)\end{array}$ & $\begin{array}{c}92.63 \\
(56.03)\end{array}$ & 0 \\
\hline C. Total food subsidy & $\begin{array}{c}334.34 \\
(100.00)\end{array}$ & $\begin{array}{c}158.07 \\
(100.00)\end{array}$ & $\begin{array}{c}69.36 \\
(100.00)\end{array}$ & $\begin{array}{c}314.30 \\
(100.00)\end{array}$ & $\begin{array}{c}165.33 \\
(100.00)\end{array}$ & $\begin{array}{c}69.01 \\
(100.00)\end{array}$ \\
\hline
\end{tabular}

(Figures in parenthesis indicates percentage to total)

Table.8 Share of food subsidy to the total food expenditure (Percentage)

\begin{tabular}{|l|c|c|c|c|c|c|}
\hline \multirow{2}{*}{ Commodity } & \multicolumn{3}{|c|}{ Rural } & \multicolumn{3}{c|}{ Urban } \\
\cline { 2 - 7 } & LIG & MIG & HIG & LIG & MIG & HIG \\
\hline A. Total food subsidy through PDS & 12.27 & 6.94 & 3.84 & 12.89 & 7.22 & 3.68 \\
\hline Rice & 0 & 0 & 0 & 0 & 0 & 0 \\
\hline Other Cereals (Wheat) & 53.84 & 86.23 & 71.76 & 94.82 & 93.78 & 87.57 \\
\hline Oil & 25.1 & 11.26 & 5.22 & 24.62 & 11.37 & 7.36 \\
\hline Sugar & 23.81 & 16.89 & 14.00 & 22.63 & 14.42 & 10.48 \\
\hline B. Food subsidy through NMS & 43.33 & 10.33 & 0 & 38.45 & 10.44 & 0 \\
\hline C. Total food subsidy & 55.6 & 17.26 & 3.84 & 51.34 & 17.66 & 3.68 \\
\hline
\end{tabular}

Table.9 Estimated coefficients for household food expenditure

\begin{tabular}{|l|c|c|c|c|c|c|}
\hline \multirow{2}{*}{$\begin{array}{l}\text { Independent } \\
\text { variable }\end{array}$} & \multicolumn{5}{|c|}{ Dependent variable: Per Capita Household Food Expenditure } \\
\cline { 2 - 7 } & LIG & MIG & HIG & LIG & MIG & HIG \\
\cline { 2 - 7 } Intercept & 456.08 & 706.02 & 417.19 & 300.36 & 299.45 & 416.83 \\
\hline Income & $0.92^{*}$ & $0.77^{*}$ & $0.62^{*}$ & $0.94^{*}$ & $0.84^{*}$ & $0.63^{*}$ \\
\hline Subsidy & $0.14^{*}$ & $0.59^{*}$ & 0.68 & $0.06^{*}$ & $0.88^{*}$ & 1.76 \\
\hline Family size & $-46.66^{*}$ & $-34.20^{*}$ & $-32.56^{*}$ & $-30.09^{*}$ & $-28.82^{*}$ & $-27.07^{*}$ \\
\hline Education & -1.19 & $4.76^{*}$ & $4.96^{*}$ & -2.13 & $0.98^{*}$ & $1.54^{*}$ \\
\hline Price of rice & 0 & 25.97 & 21.68 & 0 & $13.35^{*}$ & 10.69 \\
\hline $\begin{array}{l}\text { Price of Other } \\
\text { Cereals }\end{array}$ & -0.99 & 3.80 & $21.55^{*}$ & -0.96 & 3.47 & 6.11 \\
\hline Price of Oil & 2.37 & 5.38 & -6.41 & 0.53 & 2.42 & 4.95 \\
\hline Price of Sugar & 3.61 & 9.13 & $10.17^{*}$ & 2.10 & 0.23 & 8.34 \\
\hline$R^{\mathbf{2}}$ & 0.69 & 0.71 & 0.85 & 0.77 & 0.78 & 0.72 \\
\hline
\end{tabular}


The price of rice coefficient was positive and significant for urban MIG only. It showed that increase in price of rice would increase the per capita food expenditure for urban MIG. The price of other cereals was positive and significant for rural HIG alone. The oil price was not significant for all the income groups. The price of sugar was negative and significant for rural HIG alone. In general sign of the price coefficient for cereals, oil and sugar were mixed between the income groups.

The conclusion and policy implications are as follows;

Anti-poverty programmes and employment generating programmes such as TRYSEM, NREP and IRDP could be strengthened further to accomplish to have a better quality of life in this study region.

To generate self employment for poor in both rural and urban sectors, the institutional financing should be liberally provided with more flexibility.

Poor households met their total rice consumption through Free Rice Scheme by the Government of Tamil Nadu. Further strengthening of this scheme would ensure food and nutritional security at the grass root level population.

Pulses were the predominant and cheapest source of calorie and vegetable protein for the majority of the poor households. Hence the quantity of pulses supplied through PDS should be enhanced to ensure adequate intake of nutrition by the people.

The Noon Meal Scheme played a pivotal role to help enhance the enrolment of rural and urban LIG children. So, strengthening of NMS should be the prior strategy of the state and central institutions to ensure provision of adequate nutrition to the youth to have better human resources in the years to come.

There is strong need to improve the awareness of general public in study region about the importance of nutrition so that the households with adequate income do not suffer from under nutrition.

\section{References}

Deaton, A. and. Muellbauer, J. 1980. An almost ideal demand system. American Economic Review. 70: 312336.

Diao, X., Hazell, P., Resnick D. and Thurlow, J. 2007. The role of agriculture in development: implications for subsaharan Africa. International Food Policy Research Institute Research Report: 153.

Dreze, J. and Goyal, A. 2003. Future of midday meals. Economic and Political Weekly. 38(44): 4673-4683.

Food and Agricultural Organization of the United States 2012. The state of food insecurity in the World. Rome.

Frankenberger, T.R. 1996. The household livelihood security concept. Food and Nutrition and Agriculture. 22: 30-35.

Gilbert, C.C., Hall, G., Hegyi, A.,. Lehoux, C., Sanchez M. and Astrom A. 2010. Leveraging agriculture for improving nutrition and health. 2020 Conference: International Food Policy and Research Institute, New Delhi, India.

Gracia, A. and. Albisu, L.M. 1998. The demand for meat and fish in Spain in urban and rural areas. Agricultural Economics. 19(3): 359-366.

Headey, D.C. and Fan S. 2010. Reflections on the global food crisis: how did it happen? how did it hurt? and how can we prevent the next one? International Food Policy Research Institute Research Monograph: 165. 
Khera and Reetika. 2011. Revival of the public distribution system: evidence and explanations. Economic and Political Weekly. 46(44).

Meade, Birgit and Stacey, R. 2013. International food security assessment, 2013-2023, GFA-24. U.S.Department of Agriculture, Economic Research Service, June.

Prasad, K, Vikram, P. and Sharad, T. 2014. The impacts of reforms to the public distribution system in India's Chhattisgarh on food security. United States Department of AgricultureEconomic Research Report: 164.

Puri and Raghav. 2012. Reforming the public distribution system: lessons from Chhattisgarh. Economic and Political Weekly. 47(5).

Rapheal and Qaim. 2010. Impact of income on food security and nutrition in Nigeria. African Association of Agricultural Economists (AAAE) and 48th Agricultural Economists Association of South Africa (AEASA) Conference, Cape Town, South Africa.

Saweda and Nelson. A.W. 2010. Asset versus consumption poverty and poverty dynamics in the presence of multiple equilibria in rural Ethiopia. International Food Policy Research Institute (IFPRI) Discussion Paper: 00971.

Shenngen, F. 2011. Changing role of agriculture and food sector in Asia. International Food Policy and Research Institute.

\section{How to cite this article:}

Uma Gowri, M. and Shanmugam, T. R. 2017. Effects of Subsidy on Food Consumption Pattern in Rural and Urban Households of Western Tamil Nadu, India. Int.J.Curr.Microbiol.App.Sci. 6(4): 2112-2124. doi: https://doi.org/10.20546/ijcmas.2017.604.249 